\title{
A NEW AND PREVIOUSLY MISIDENTIFIED SPECIES OF TRISETELLA (PLEUROTHALLIDINAE: ORCHIDACEAE) FROM SOUTHEAST ECUADOR
}

\author{
Luis E. Baquero ${ }^{1,2,3}$ \& Adriana L. Mogrovejo ${ }^{2}$
}

${ }^{1}$ Grupo de Investigación en Biodiversidad, Medio Ambiente y Salud BIOMAS, Carrera de Ingeniería Agroindustrial y Alimentos, Facultad de Ingeniería y Ciencias Agropecuarias, Universidad de Las Américas, Calle José Queri, Quito, Pichincha, 170137, Ecuador.

${ }^{2}$ Grupo Científico Calaway Dodson: Investigación y Conservación de Orquídeas del Ecuador, Quito, 170510, Pichincha, Ecuador.

${ }^{5}$ Author for correspondence: lbaquero@hotmail.com

\begin{abstract}
Trisetella pachycaudata, a new species in the subtribe Pleurothallidinae, was discovered in the Zamora Chinchipe province of southeast Ecuador, and it is described here. Trisetella pachycaudata is compared with the most similar species (and others with which it has been confused in cultivation), T. triglochin, T. strumosa, and T. vittata. It differs from them in the flowers with a much thicker apex of the sepaline tails (the thickest in the genus), and the petals expanded at the labellar margin, with the cuspidate apices erose on the upper margin and entire at the lower margin.

Resumen. Trisetella pachycaudata, una nueva especie de la subtribu Pleurothallidinae, ha sido descubierta en la provincia de Zamora Chinchipe al sureste de Ecuador y es descrita aquí. Trisetella pachycaudata es comparada con las especies más similares (y con las que se le ha confundido en cultivo) T. triglochin, T. strumosa, y T. vittata. Se diferencia de estas por producir flores con los ápices de las caudas sepalinas más gruesas en comparación con cualquier otra especie conocida del género, los pétalos expandidos hacia el margen labelar, con el margen superior eroso mientras el margen inferior es entero y cuspidado.
\end{abstract}

Key words / Palabras Clave: Trisetella strumosa, Trisetella triglochin, Trisetella vittata, Zamora Chinchipe

Introduction. The first species of Trisetella was described as Masdevallia triaristella Rchb.f. by Gustav Reichenbach in 1876. Due to the particular morphological features of this species compared to the rest of the members of Masdevallia, Reichenbach created a new subdivision for this particular species called Triaristellae described in Masdevallia a total of five species in what is now known as Trisetella (Luer 1989). Besides this group of weird Masdevallia species, Kränzlin included in the Triaristellae group, a couple of species belonging to Barbosella Schltr. (Luer 1989). In 1976, Brieger recognized all the species included in the Triaristellae subdivision as belonging to a new genus (Brieger 1975). However, the name Triaristella was already used for a group of fossil fungi, so it was replaced with Trisetella in 1980 by Luer $(1980,1989)$.

The species of Trisetella are recognized by the small to tiny plants with thick, sometimes terete, leaves, the slender inflorescences are successively few-flowered and congested racemes are born low on the ramicaul. All the species have sepaline tails, and, except for T. hoeijeri Luer \& Hirtz, all the species have the lateral sepals completely connate into a more or less concave synsepal. In addition, all the species have a lip cleft to the column foot with two lobes towards the base and two to five longitudinal carinae in the disc (most of the species have two). There is molecular evidence that Trisetella forms a monophyletic clade, supporting its recognition as a good genus (Luer 1989, Karremans 2016)

Orchid species from Ecuador are commonly illegally exported for cultivation even before the species are described. The names given by the exporter to these species are normally based on the morphological similarity to other known species. This is the case with Scaphosepalum tarantula Baquero \& Hirtz (sold as $S$. fimbriatum Luer \& Hirtz “pink”), S. luannae Baquero [sold as S. breve (Rchb.f.) Rolfe “pink”], Platystele baqueroi Jost \& Iturralde [known as P. caudatisepala 

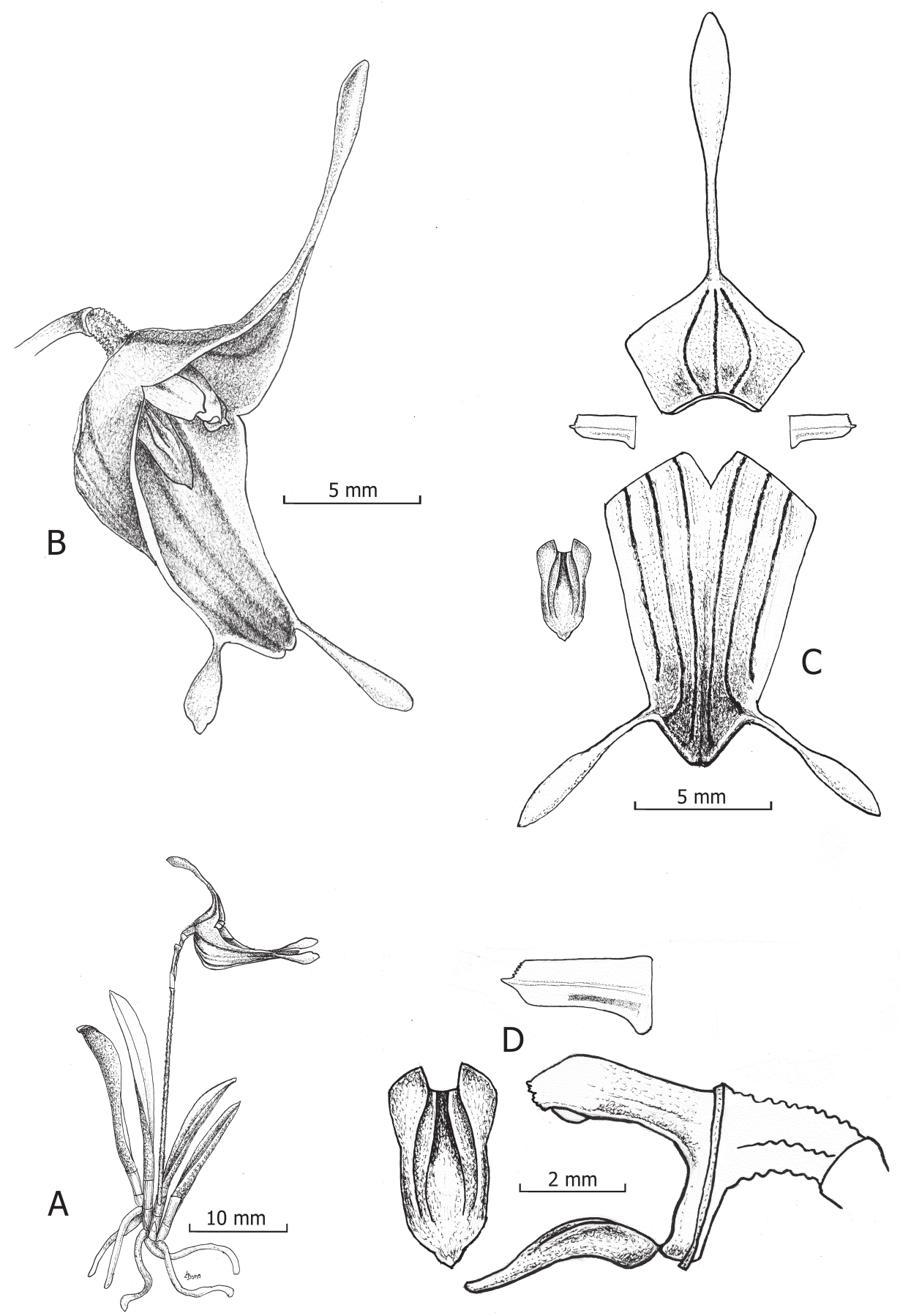

FIGURE 1. Illustration of Trisetella pachycaudata Mogrovejo-Herrera \& Baquero. A. Habit. B. Flower. C. Dissected perianth.

D. Side view of column and lip, adaxial view of lip and petal. Drawn by Luis E. Baquero from the holotype (LB 3139). 


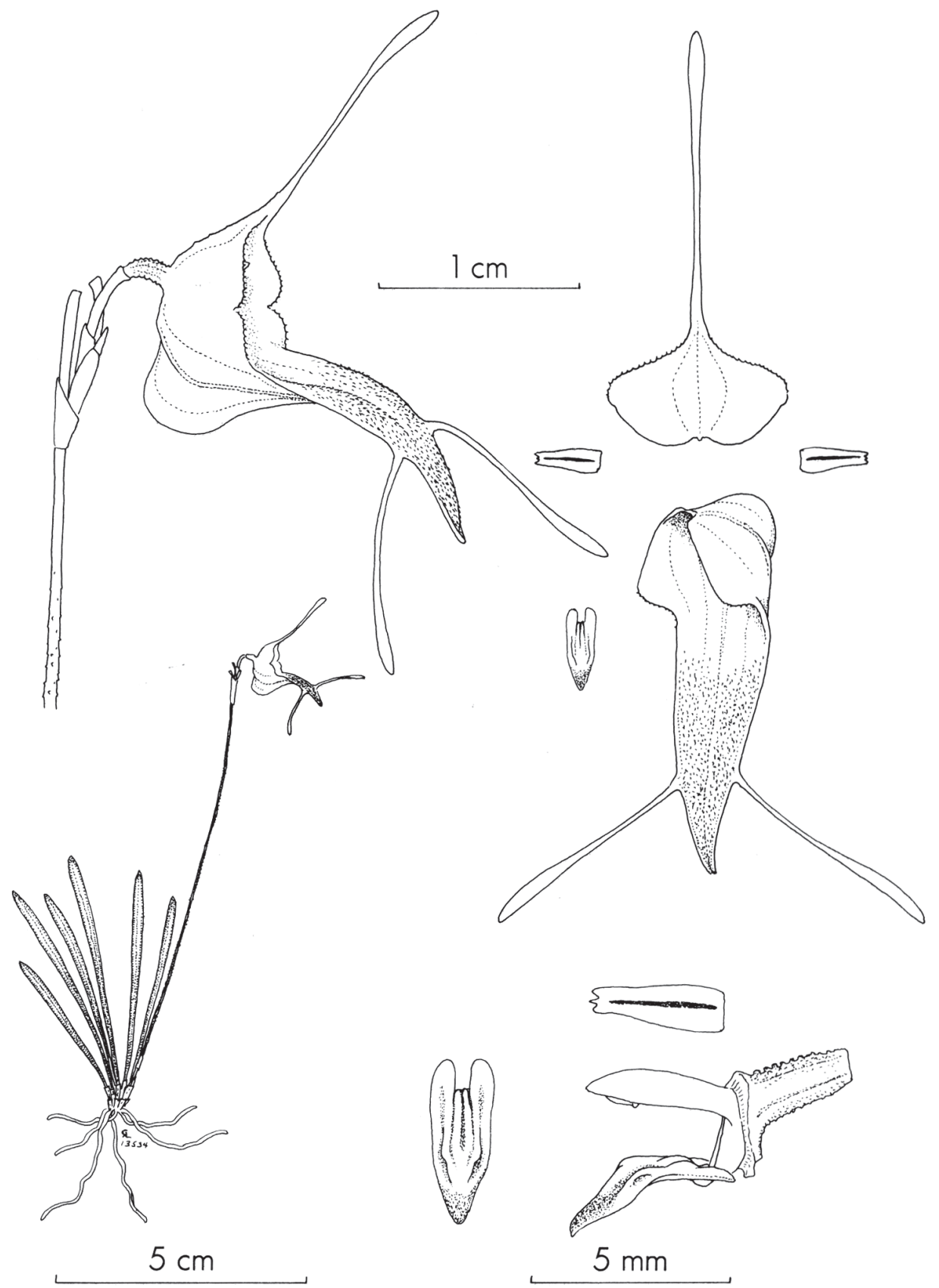

FIgURE 2. Illustration of Trisetella strumosa by C. Luer, taken from the Systematics of the genus Trisetella: Monographs in systematics botany of the Missouri Botanical Garden, volume 31, plate 16. Reproduced with kind permission of Missouri Botanical Garden Press. 
(C.Schweinf.) Garay in cultivation] and Dracula trigonopetala Gary Mey. \& Baquero [sold as D. radiosa (Rchb.f.) Luer], to name a few (Meyer et al. 2012, Jost \& Iturralde 2017, Baquero et al. 2018, Baquero 2019). Also, according to Yeager et al. (2020), about twice the number of plants of Lepanthes Sw. exported out of Ecuador up to 2016 belong to unidentified species (including new species to science) versus the total amount of plants belonging to identified species of Lepanthes. Nevertheless, several new species of Ecuadorian orchids are not always exported as misidentified species intentionally and are due to common taxonomic errors in complex groups.

The new species of Trisetella from southeast Ecuador, treated here, is not an exception; it was exported out of this country and it has been misidentified in cultivation as T. triglochin (Rchb.f) Luer, T. strumosa Luer \& Andreetta, or T. vittata (Luer) Luer. However, plants of this species have recently been discovered growing in nature, and the species is described here and compared to other similar species.

Materials and methods. Material of the new species was collected in Ecuador during a research on orchids of the Cordillera del Cóndor, under Research Permit No. 008-2016-IC-FLO-DNB/MA. Specimens were cultivated and photographed in the Jardín Botánico de Quito, Ecuador. Fresh flowers were preserved in $70 \%$ ethanol and $1 \%$ glycerol. Living and stored material were examined for morphological and taxonomic comparisons, the taxonomic revision of Trisetella by Luer (1989) and other original descriptions from related species were reviewed and compared. Digital images were taken with a Nikon D5100 camera with an AF-S Micro Nikkor $60 \mathrm{~mm}$ lens.

\section{TAXONOMIC TREATMENT}

\section{Trisetella pachycaudata Mogrovejo-Herrera \&} Baquero, sp.nov. (Fig. 1-4)

TYPE: Ecuador. Zamora Chinchipe: between Palanda and Zumba: 4 38' 18” S, 79 19' 415” W, 1968 m, 25 Jan 2017, L. Baquero 3139 (holotype, QCNE).

DiAgnosis: Trisetella pachycaudata is similar to $T$. strumosa Luer \& Andreetta, from which it differs in the small plant, up to $22 \mathrm{~mm}$ ( $v s$. medium in size, up to $50 \mathrm{~mm}$ in size), the entire sepals ( $v s$. and minutely ciliate), transversely ovate dorsal sepal ( $v s$. transversely obovate), glabrous sepals with raised veins ( $v s$. minutely short-pubescent veins not raised), the lateral sepals connate into a concave synsepal ( $v s$. connate into a retrorse synsepal with a basal mentum), thickly clavate tails of the sepals ( $v s$. clavate), petals oblong dilated at the base of the labellar margin ( $v s$. oblong-ovate), the apex of the petals truncate, cuspidate, erose at the upper margin, and entire at the lower margin ( $v s$. truncate, tridentate), lip rose-colored channeled at the center of the disc ( $v s$. not channeled disc), and the clinandrium crenate (vs. entire) (Fig. 2-4).

Plant small, up to $25 \mathrm{~mm}$, epiphytic, caespitose, roots slender $0.5 \mathrm{~mm}$ thick. Ramicauls $3 \mathrm{~mm}$ long, enclosed by $2-3$ tubular sheaths. Leaf olive-green adaxially, speckled with purple abaxially, erect, linear, conduplicate, fleshy, semiterete, apex acute minutely retuse at the tip, wedge-shaped at the base 13-22 $\times$ 2.0-2.3 mm. Inflorescence a few-flowered (2-3), congested, successive raceme, with an erect, slender, verrucose peduncle $24 \mathrm{~mm}$ long, with a bract close to the base, from low on the ramicaul, floral bracts $1.7 \mathrm{~mm}$ long, pedicel $4.5-5.7 \mathrm{~mm}$ long, ovary 1.8 $\mathrm{mm}$ long, verrucose. Dorsal sepal waxy yellow, suffused with red-brown, glabrous, transversely ovate, concave, $7.0 \times 5.6 \mathrm{~mm}$, with three dark red-brown veins, raised internally from the base towards the middle of the blade, connate to the lateral sepals for $3.8 \mathrm{~mm}$ to form a sepaline cup, margins entire with a thick, clavate yellow tail $6.7-7.1 \mathrm{~mm}$ long. Lateral sepals waxy yellow, suffused with red-brown from the apex towards $3 / 4$ of its length, with six dark redbrown veins raised internally from the base towards the apex, concave, $11.9 \times 8.9 \mathrm{~mm}$, connate for 10.9 $\mathrm{mm}$ into an emarginate synsepal, with a $4.5 \mathrm{~mm}$ long mentum, narrowing from the base towards the apex, entire margins with a pair of yellow, thickly clavate tails produced laterally $5.3 \mathrm{~mm}$ long. Petals translucent yellow, suffused with a purple line slightly below the midvein, which extends for two-thirds of the length of the petal, concave, oblong, broadly dilated at the base of the labellar margin, $2.6 \times 1.4 \mathrm{~mm}$, with apex truncate, cuspidate, erose at the upper margin, and entire at the lower margin. Lip rose-colored, 
oblong-ovate, $3.2 \times 1.4 \mathrm{~mm}$, with a pair of slightly inflexed, thickened lobes at the base, the apex narrowly obtuse and thickened, the disc with a low pair of longitudinal carinae extending from the base of the lip towards the middle, separated by a wide central channel, flanked by another, thicker pair of low, longitudinal carinae, extending for two-thirds of the length of the lip, channeled centrally, the cordate base hinged to the compressed apex of the column foot. Column yellowish-green suffused with rose, clinandrium crenate, semiterete, $2.9 \mathrm{~mm} \times 0.7 \mathrm{~mm}$, the foot $1.6 \mathrm{~mm}$ long. Pollinia and anther cap not seen.

ЕтумоLogy: From the Greek pachy "thick" and Latin caudatus "caudate, ending with a tail-like appendage", in reference to the thick (the thickest know for the genus) sepaline tails.

Habitat AND CONSERVATION STATUS: Trisetella pachycaudata was found in southeast Ecuador growing in a cloud forest of the Cordillera del Cóndor, between Palanda and Zumba. The southeast Ecuador is the area with the highest diversity of the genus Trisetella, with ten described species (Luer 1989). Trisetella strumosa is known from further north, Morona Santiago Province, T. vittata is restricted to the western Andes of Ecuador, and T. triglochin is a widely distributed species that has not been found growing sympatrically with T. pachycaudata (Luer 1989). Currently, the Cordillera del Cóndor is extensively affected by mining activity due to government concessions and illegal mining. Although T. pachycaudata has not been witnessed to be affected directly, its populations are considered to run a high risk of extinction due to the destructive nature of imminent mining activities. Very close to where the plants of $T$. pachycaudata were discovered growing, illegal mining (developed by local people) takes place and was observed by the authors. An excellent example of a threatened species is the recently described Lepanthes vere-aurum Baquero \& Donoso. The type locality of this species has been logged, and the population disappeared (Baquero et al. 2020).

TAXONOMICAL NOTES: Trisetella pachycaudata has been exported and grown outside of Ecuador by hobbyists under different names (T. strumosa, T. triglochin, and T. vittata) (Fig. 3). In general terms, T. pachycaudata is immediately recognized by a unique combination of morphological characters: the clavate tails of the sepals with the thickest apex in the genus, waxy yellow at the base synsepal, suffused with red-brown towards the apex and with dark red-brown veins raised internally from the base towards the apex, a rosy lip with four longitudinal carinae at the disc, with the two central carinae separated by a wide central channel, and a crenate clinandrium (Fig. 1-2, 3F).

Trisetella pachycaudata is not a member of the $T$. triglochin species-complex because of the conspicuously verrucose peduncle (occasionally slightly or sparsely scabrous in T. triglochin), the veins raised internally from the base towards the apex at the adaxial side of the synsepal (absent in T. triglochin), the clavate tails extremely thick at the apex (in T. triglochin some populations have clavate tails but not as thick as in $T$. pachycaudata), the petals broadly dilated at the base of the labellar margin, erose at the upper margin and entire at the lower margin, the acuminate apex (the base of the petals not broadly dilated in T.triglochin with the apex erose to tridenticulate), and the lip with four longitudinal carinae at the disc (2 carinae in T. triglochin) (Fig. 1-3). Trisetella pachycaudata is different from T. strumosa in having thicker apices of the tails and the absence of a retrorse mentum, and a glabrous synsepal compared to the minutely short-pubescent synsepal of $T$. strumosa. The petals of $T$. pachycaudata are broadly dilated at the labellar margin, erose at the upper margin, and entire at the lower margin at the cuspidate apex vs. the petals of T. strumosa, which are oblong and tridentate at the apex. Also, T. pachycaudata has a rosy lip with a wide central channel at the middle of the disc, different from the red-brown lip with a cramped, central channel (Fig. 3). Although the veins of the synsepal in T. pachycaudata are reminiscent of what is seen in T. vittata, the tails of the synsepal in both species are born from different parts, directly from the apex in T. vittata and laterally in T. pachycaudata. Again, the extremely thick apices of the sepaline tails in $T$. pachycaudata separate it from T. vittata (Fig. 3).

The thick broadenings of the apices of the sepaline tails in T. pachycaudata (Fig. 2) are similar to the osmophores on the dorsal sepal and petals of 

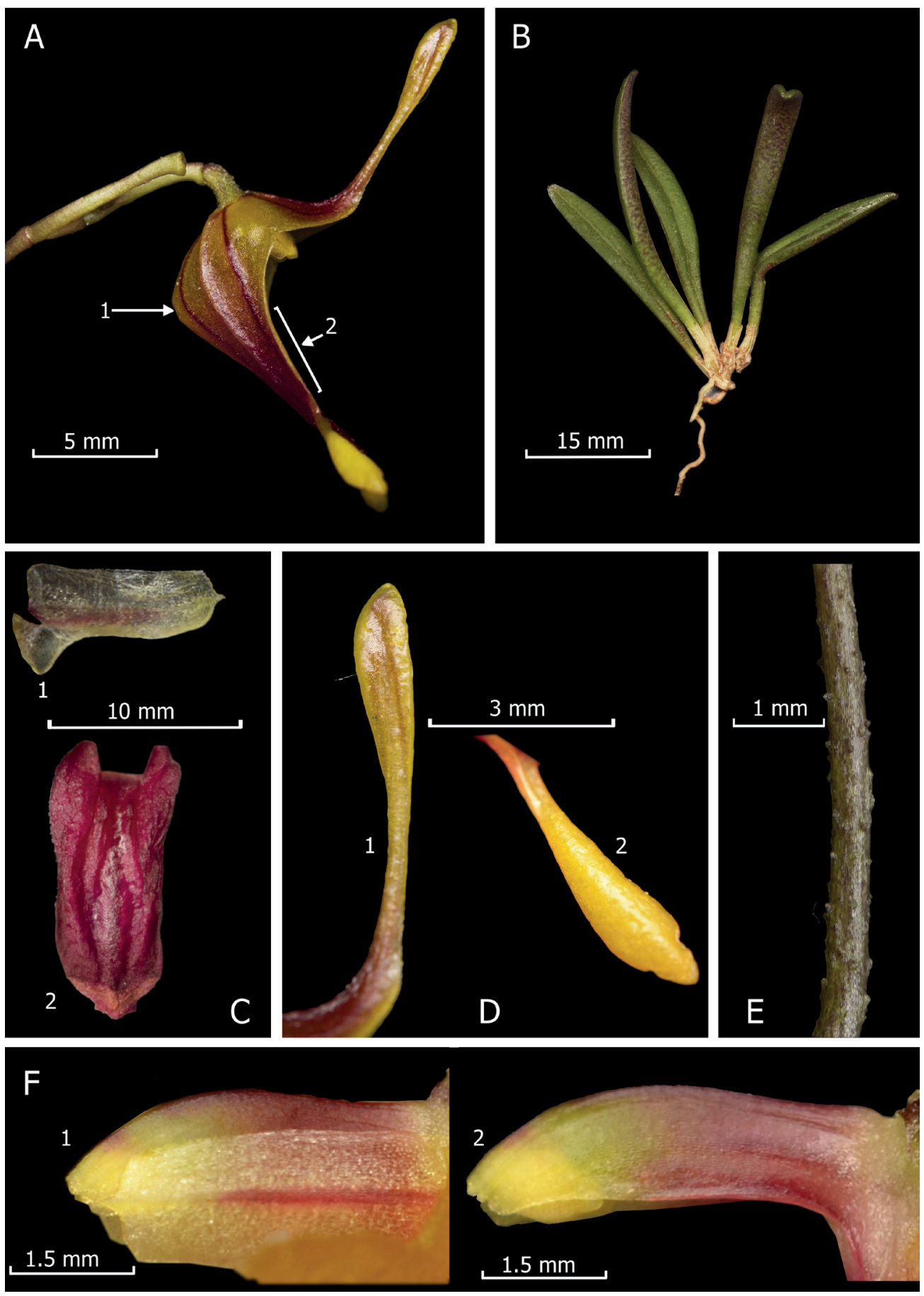

Figure 3. Trisetella pachycaudata Mogrovejo-Herrera \& Baquero. A. Flower, side view, A1. Mentum of the flower, A2. Entire margin of the sepals. B. Plant. C. Adaxial view of a petal (1) and the lip (2). D. Thickened tails of the sepals, D1. Tail of the dorsal sepal, D2. Tail of a lateral sepal. E. Verrucose peduncle. F. Lateral view of the column and petal: F1. crenate clinandrium and apex of the petal; F2. Lateral view of the column with the crenate clinandrium withouth the petal. Photos by Luis E. Baquero from the holotype (LB 3139). 

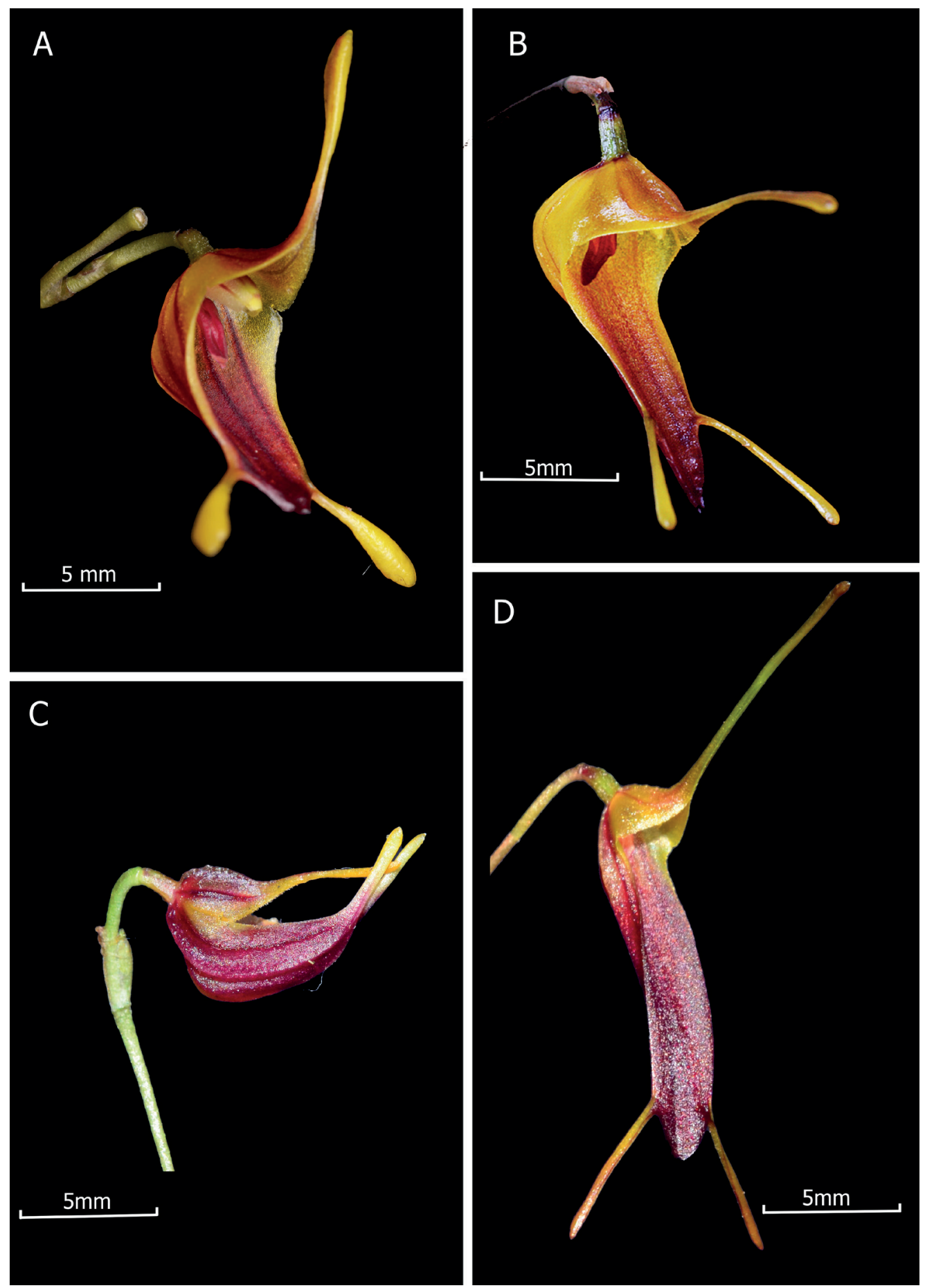

Figure 4. Comparison of Trisetella pachycaudata Mogrovejo-Herrera \& Baquero with the most similar species (and species it has been confused with). A. Trisetella pachycaudata. B. Trisetella strumosa Luer \& Andreetta. C. Trisetella vittata (Luer) Luer. D. Trisetella triglochin (Rchb.f) Luer. Photos by Luis E. Baquero (A, from the holotype, C and D) and Thomas Ditlevsen (B). 
some species of Restrepia Kunth (Millner \& Baldwin 2016). Dressler (1993) defined the osmophores as floral glands specialized in the biosynthesis and secretion of floral fragrances. Also, osmophores are often involved in deceptive pollination in the Pleurothallidinae (Millner \& Baldwin 2016). According to Pridgeon \& Stern (1983), osmophores may enable the pollinator to locate flowers by scent trails, increasing as the insect approaches the flower. No studies could confirm the presence of osmophores in Trisetella but the morphology of the thickened apices of the tails in several species resemble such. More studies need to be developed, but in the case that these structures are osmophores, we speculate that the thickness and shape of the tails could be regarded as diagnostic characters, considering the ecological and evolution- ary implications of differences in the flowers' interactions with their pollinators.

AcKNOWLEDGEMENTS. We acknowledge Universidad de Las Américas (UDLA) for funding research on orchids in Ecuador. The Ministerio del Ambiente del Ecuador for issuing the Environmental Research Permit No. 008-2016-ICFLO-DNB/MA. The authors acknowledge permission from Missouri Botanical Garden Press, St. Louis, for the use of plate 16, on page 107 from Icones Pleurothallidinarum VI: Systematics of Pleurothallis Subgenus Ancipitia, Subgenus Scopula, and Trisetella. Addendum to Porroglossum (Orchidaceae) included in Figure 2. We thank Thomas Ditlevsen for his photograph of Trisetella strumosa. Finally, we are grateful to the Editor and the anonymous reviewers for suggestions on the manuscript.

\section{LiTERATURE CITED}

Baquero, L. E. (2019). Scaphosepalum luannae, a new species, and Scaphosepalum anchoriferum (Orchidaceae: Pleurothallidinae) from north-western Ecuador. Lankesteriana, 19(3), 271-279. https://doi.org/10.15517/LANK.V1913.39971

Baquero, L. Donoso, J. J. \& Jimenez, M. M. (2020). A New Gold-Colored Lepanthes (Pleurothallidinae-Orchidaceae) from Southeast Ecuador. Lankesteriana, 20(2), 257-262. 10.15517/lank.v20i2.43556

Baquero, L. E., Hirtz, A. \& Iturralde, G. (2018). Scaphosepalum tarantula (Orchidaceae: Pleurothallidinae), a new species from Ecuador. Lankesteriana, 18(3), 231-237. https://doi.org/10.15517/lank.v18i3.35605

Brieger, F. G. (1975). Tribus: Arethusae-287. Triaristella. In: F. G. Brieger, R. Matatsch, K. Senghas (eds.), Rudolf Schlechter, Die Orchideen. Third edition (pp. 385-448). Berlin: Verlag Paul Parey.

Dressler, R. (1993). Flowers (pp. 30-31) In: Dressler Phylogeny and Classification of the Orchid Family. Structure and other evidence of relationship. Cambridge: Cambridge University Press.

Jost, L. \& Iturralde, G. (2017). A showy new Platystele (Pleurothallidinae: Orchidaceae) from northwest Ecuador. Lankesteriana, 17(1), 55-60. https://doi.org/10.15517/lank.v17i1.28479

Karremans, A. P. (2016). Genera Pleurothallidinarum: An updated phylogenetic overview of Pleurothallidinae. Lankesteriana, 16(2), 219-241. https://doi.org/10.15517/lank.v16i2.26008

Luer, C. A. (1980). Trisetella, a new name in the Pleurothallidinae. Phytologia, 47, 57.

Luer, C. A. (1989). Icones Pleurothallidinarium VI. Systematics of Pleurothallis Subgenus Ancipitia, Subgenus Scopula and Trisetella. Monographs in Systematic Botany from the Missouri Botanical Garden, 31, 69-122.

Meyer, G. E., Baquero, L. \& Cameron, K. M. (2012). A New Ecuadorian species of Dracula: Pleurothallidinae (Orchidaceae). Orchideen Journal, 19, 107-113.

Millner, H. J. \& Baldwin, T. C. (2016). Floral micromorphology of the genus Restrepia (Orchidaceae) and the potential consequences for pollination. Flora: Morphology, Distribution, Functional Ecology of Plants, 225, 10-19. https://doi. org/10.1016/j.flora.2016.09.007

Pridgeon, A. \& Stern, W. (1983). Ultrastructure of osmophores in Restrepia (Orchidaceae). American Journal of Botany, $70(8), 1233-1243$.

Reichenbach (1876). New Garden Plants. Masdevallia triaristella. The Gardener's Chronicle, new series, 6(138), 226.

Yeager, J., Baquero, L. E. \& Zarling, A. (2020). Mediating ethical considerations in the conservation and sustainable biocommerce of the jewels of the rainforest. Journal for Nature Conservation, 54, 1-8. https://doi.org/10.1016/j. jnc 2020.125803 